Hydrol. Earth Syst. Sci. Discuss., 6, 5085-5114, 2009 www.hydrol-earth-syst-sci-discuss.net/6/5085/2009/ (C) Author(s) 2009. This work is distributed under the Creative Commons Attribution 3.0 License.
Hydrology and Earth System Sciences Discussions

Papers published in Hydrology and Earth System Sciences Discussions are under open-access review for the journal Hydrology and Earth System Sciences

\title{
Consumptive water use associated with food waste: case study of fresh mango in Australia
}

B. G. Ridoutt ${ }^{1}$, P. Juliano ${ }^{2}$, P. Sanguansri ${ }^{2}$, and J. Sellahewa ${ }^{3}$

${ }^{1}$ CSIRO Materials Science and Engineering, Private Bag 10, Clayton South, Victoria 3169, Australia

${ }^{2}$ CSIRO Food and Nutritional Sciences, Private Bag 16, Werribee, Victoria 3030, Australia

${ }^{3}$ CSIRO Food and Nutritional Sciences, P. O. Box 52, North Ryde, NSW 2113, Australia

Received: 23 June 2009 - Accepted: 10 July 2009 - Published: 23 July 2009

Correspondence to: B. G. Ridoutt (brad.ridoutt@ csiro.au)

Published by Copernicus Publications on behalf of the European Geosciences Union.

HESSD

$6,5085-5114,2009$

Consumptive water use associated with food waste

B. G. Ridoutt et al.

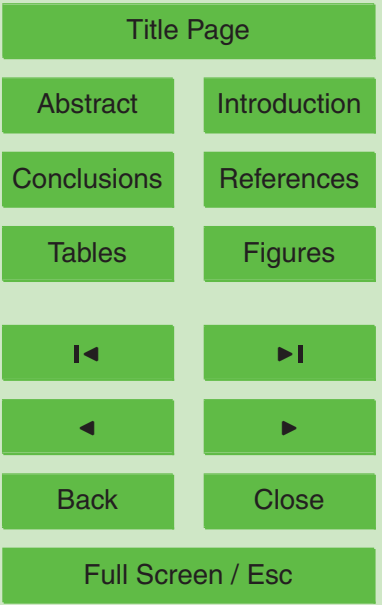

Printer-friendly Version

Interactive Discussion 


\section{Abstract}

In many parts of the world, freshwater is already a scarce and overexploited natural resource, raising concerns about global food security and damage to freshwater ecosystems. This situation is expected to intensify with the FAO estimating that world 5 food production must double by 2050 . Food chains must therefore become much more efficient in terms of consumptive water use. For the small and geographically welldefined Australian mango industry, having an average annual production of $44692 \mathrm{t}$ of marketable fresh fruit, the average virtual water content (sum of green, blue and gray water) at orchard gate was $2298 \mathrm{I} \mathrm{kg}^{-1}$. However, due to wastage in the distribution and consumption stages of the product life cycle, the average virtual water content of one $\mathrm{kg}$ of Australian-grown fresh mango consumed by an Australian household was 5218I. This latter figure compares to an Australian-equivalent water footprint of $217 / \mathrm{kg}^{-1}$, which is the volume of direct water use by an Australian household having an equivalent potential to contribute to water scarcity. Nationally, distribution and consumption

The world faces a food security challenge of massive proportion. Currently, there are an estimated 963 million undernourished people in the world, representing about $15 \%$ of the total population (FAO, 2008a). Yet demand for food is also forecast to double by 2050 based on projected population and socio-economic growth (FAO, 2008b). While agricultural yields have shown impressive increases over the twentieth century, largely due to genetic improvements, irrigation, fertilization and the use of pesticides, envi-

\section{HESSD}

$6,5085-5114,2009$

Consumptive water use associated with food waste

B. G. Ridoutt et al.

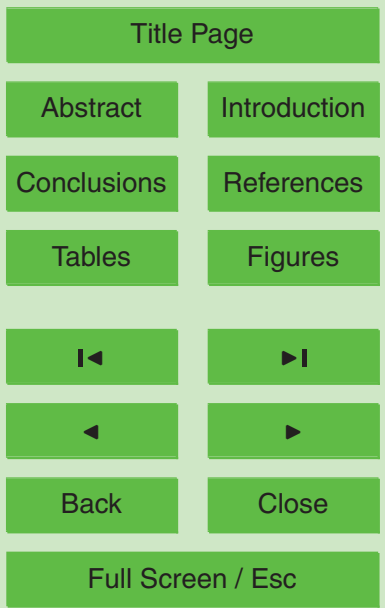

Printer-friendly Version

Interactive Discussion 
ronmental sustainability has in many locations been compromised (Nellemann et al., 2009). One of the greatest constraints on current and future food production is the availability of freshwater, which is now a scarce and overexploited resource in many parts of the world (Bartram, 2008; Falkenmark, 2008). The Aral Sea tributaries, Chao 5 Phraya, Colorado, Ganges, Huai, Indus, Jordan, Lake Chad tributaries, Murray, Nile, Rio Grande and Yellow are among a growing list of rivers where consumptive water use by agriculture has reduced flows severely, in some cases causing flows to become intermittent in the lower reaches (Falkenmark and Lannerstad, 2005). The Punjab province of Pakistan, the Gujarat and Rajasthan states of India, and the North China 10 Plain are but a few of the major food producing regions where groundwater is being extracted at unsustainable rates (Falkenmark and Lannerstad, 2005).

Consumptive water use refers to the removal of water from a local hydrological system, thereby rendering it unavailable for further use (Falkenmark and Lannerstad, 2005; Liu et al., 2009). That is, there is no verifiable return flow. Present consump15 tive water use for global food production has been estimated at between 16950 and $18600 \mathrm{~km}^{3} \mathrm{yr}^{-1}$ (Rockström et al., 2007, 2009) consisting of around 35\% green water consumption by rainfed croplands, $10 \%$ blue water consumption by irrigated croplands and $55 \%$ green water consumption by pastures. These results are broadly consistent with separate estimates of $3823 \mathrm{~km}^{3} \mathrm{yr}^{-1}$ of consumptive water use for 17 major crops representing $63 \%$ of global cropland area, with $81 \%$ being green water (Liu et al., 2009). Blue water is derived from surface and groundwater sources whereas green water is derived directly from natural rainfall over agricultural lands. These figures highlight the dominance of green water in current global food production, even though irrigation accounts for around $70 \%$ of all freshwater withdrawals (UNESCO-WWAP, 2006). However, what is alarming from both a food security and environmental sustainability perspective is that at current rates of agricultural water use efficiency, an estimated additional $5700 \mathrm{~km}^{3} \mathrm{yr}^{-1}$ of freshwater will be needed to meet the demand for food in 2050 (Rockström et al., 2009). Since the availability of additional blue water resources is limited, a range of strategies have been proposed for achieving future food

HESSD

$6,5085-5114,2009$

Consumptive water use associated with food waste

B. G. Ridoutt et al.

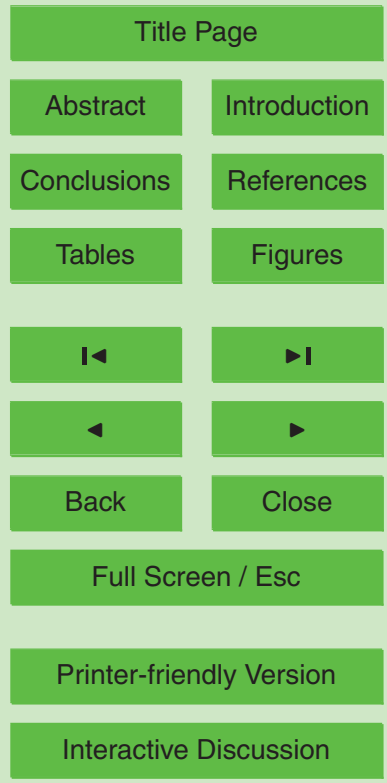

Interactive Discussion 
security. These include the continued conversion of natural ecosystems to new agricultural lands to access greater volumes of green water, water productivity improvements in agriculture (i.e. so-called crop per drop improvements), shifting diets to minimise the consumption of animal products which have high consumptive water requirements, 5 water saving through increasing trade in agricultural commodities, and reducing food chain losses (Rockström, 2003; Chapagain et al., 2006a; Yang et al., 2006; Lundqvist et al., 2007; Rockström and Barron, 2007; Rockström et al., 2007, 2009; Yang and Zehnder, 2007; Liu and Savenije, 2008; Liu et al., 2008; Nellemann et al., 2009).

Regarding food chain losses, it is commonly believed that these are in the order of 1030 to $50 \%$ between farm and fork (Henningsson et al., 2004; Kader, 2005; Bloom, 2007; Lundqvist et al., 2008; Meeusen and Hagelaar, 2008), although detailed characterisation is lacking in Australia (Morgan, 2009) and elsewhere. Substantial variation from one food chain to another is likely. Broadly speaking, a contrast exists between developing countries where losses tend to be high toward the beginning of the food chain due to poor harvesting, storage and transport, and developed countries where losses in wholesaling, retailing and consumption often predominate (Lundqvist et al., 2008). This is due to the expectation by consumers in developed countries for produce in perfect condition and a tiny blemish or deviation from optimal ripeness can exclude a product from consumer consideration. In describing food waste, a distinction must made between avoidable food waste, representing food eaten, and unavoidable food waste, representing bones, peel, pips and stones and the like which are generally inedible, but nonetheless may have other beneficial uses.

Supply chain waste, from farm to consumer, naturally represents a cost to the firms involved in terms of unrealised sales, excessive raw material usage and disposal costs 25 (Henningsson et al., 2004; Pagan and Prasad, 2007). However, the effort and expense associated with reducing waste does not always justify the necessary investments when viewed from a purely financial perspective. One of the reasons why firms are not more active in reducing waste is that many of the environmental costs are externalised. Recently, however, there has been a growing interest in making trans-
HESSD

6, 5085-5114, 2009

Consumptive water use associated with food waste

B. G. Ridoutt et al.

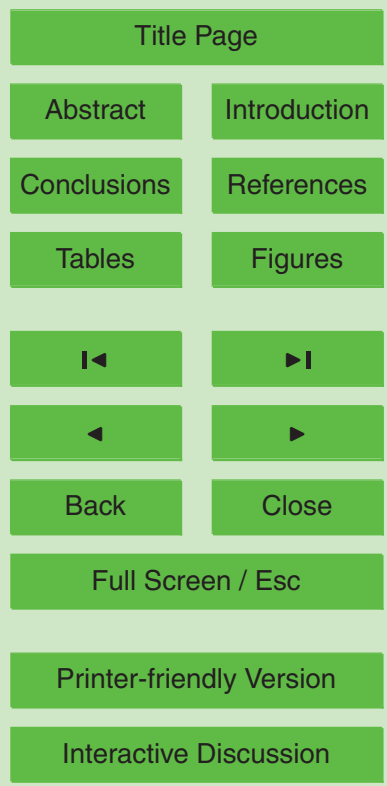


parent the environmental impacts of the production and consumption of goods and services (Lebel and Lorek, 2008). Many businesses are seeking to demonstrate good corporate citizenship by measuring, reporting and addressing negative social and environmental impacts arising from their operations and product life cycles (Chapagain and 5 Orr, 2009). The recent popularisation of carbon footprinting, disclosure and labelling are evidence of this. In addition, product environmental labelling initiatives in many jurisdictions are enabling consumers to become more aware of the impacts of their purchasing decisions and thereby take greater responsibility for their consumption patterns. Such developments are creating new incentives for reducing food waste. As one 10 example, US foodservice provider Bon Appetit has announced a plan to cut food waste by $20 \%$ with the intention of cutting greenhouse gas emissions by more than $2000 \mathrm{t}$ $\mathrm{CO}_{2}-\mathrm{eq} \mathrm{yr}^{-1}$ (Environmental Leader, 2009). Another example, driven by public policy, is the Love Food Hate Waste campaign in the UK (www.lovefoodhatewaste.com).

Food that is not consumed or used in some other beneficial way represents a waste 15 of all of the resources that were used in its production and distribution, such as water. As already mentioned, water availability is a critical concern to future food security and environmental sustainability. Our research concerns the mapping of food waste through the distribution and consumption stages of the product life cycle and the use of water footprinting to assess the impact on water resources. This case study focuses on the small and geographically well-defined Australian mango industry, having an average annual production of $44692 \mathrm{t}$ of marketable fresh fruit. To our knowledge, this is the first application of water footprinting to assess the impact of food waste on water resources. As noted by Yang and Zehnder (2007), water footprinting studies in the past have been overwhelmingly concerned with describing national and global-level virtual water flows in relation to international trade and have typically used crude statistics obtained from international databases. By using location specific data in this case study, we also seek to demonstrate the relevance of water footprinting in addressing local-scale problems regarding food production and water scarcity.
HESSD

$6,5085-5114,2009$

Consumptive water use associated with food waste

B. G. Ridoutt et al.

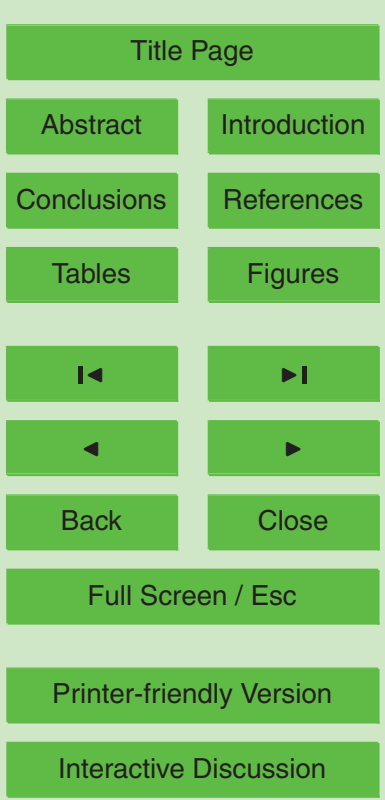




\section{Methodology and data}

\subsection{Mapping of food chain waste}

Mangoes are an important tropical fruit, accounting for approximately $50 \%$ of all tropical fruits produced worldwide and with world production forecast to exceed 30 million t by

52010 (FAO, 2003). In contrast, the Australian mango industry is small, accounting for considerably less than $1 \%$ of world production, making it amenable to case study analysis. Although mango has been grown in Australia since early European settlement (mid 1800's), an organised industry formed in the late 1970's (Bally et al., 2000). The industry is mainly focussed on supplying fresh mango for Australian household consumption with lesser volumes exported to countries such as Singapore, Hong Kong, Malaysia, UAE and Japan. There are seven major growing regions (Table 1).

In this study, the food chain for Australian-grown fresh mango to Australian households was mapped. This food chain fluctuates significantly from year to year due mainly to the variability in local fresh mango production, which in recent years has ranged from $33445 \mathrm{t}$ (season 2005/06) to $59985 \mathrm{t}$ (season 2006/07). As such, averages were calculated over a six-year period, from season 2003/04 to season 2008/09, for which data were available. Industry representatives (Australian Mango Industry Association, Horticulture Australia Limited) provided data on the production of fresh and processing mangoes. Specifically, these data represent the shipment of marketable mangoes from

the regional packing stations. Not included are mangoes grown but deemed unsalable, for which statistics are not collected in Australia. Data on the import and export of fresh mango were obtained from the World Trade Atlas (Global Trade Information Services, Inc.).

Data on retail sales of fresh mango were provided by Horticulture Australia Limited,

based on retail scan data from one of Australia's national chain store retailers and household survey data describing the market share for the various retail distribution channels for fresh mango in Australia. The proportion of fresh mango sold to households and the food service sector was estimated at 85 and $15 \%$ respectively, based on

HESSD

$6,5085-5114,2009$

Consumptive water use associated with food waste

B. G. Ridoutt et al.

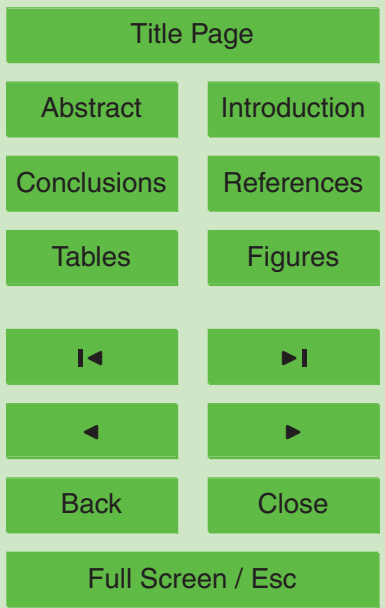

Printer-friendly Version

Interactive Discussion 
advice from industry experts. The mass balance of fresh mango shipments from regional packing stations, imports, exports and sales to retail and food service was used to estimate waste in the distribution stage, taking into account weight losses of $5.4 \%$ (i.e. $0.2 \%$ per day over 27 days which is typical for the Australian fresh mango food 5 chain, Macnish et al., 1997). In the consumer stage, avoidable waste was estimated at $26.3 \%$, i.e. the same proportion of the weight of fruit that was found to be thrown away in a detailed UK study of household waste (WRAP, 2008). No equivalent study of household waste has been undertaken in Australia. Unavoidable waste (peel and stone) was estimated at $20 \%$ of consumed fruit.

\subsection{Crop water requirements}

For each of the major mango producing regions of Australia (Table 1), crop water requirements $\left(\mathrm{mm} \mathrm{yr}^{-1}\right)$ and effective rainfall $\left(\mathrm{mm} \mathrm{yr}^{-1}\right)$ were calculated using CropWat for Windows Version 4.3 (FAO, 1998), using climate data obtained from the New_LocClim local climate estimator (FAO, 2005). The use of locally relevant climate 15 data overcomes a recognised weakness (Chapagain and Orr, 2009; Liu et al., 2007) of many previous water footprint studies which have used national average climate data, which especially for a large country like Australia may poorly represent local growing conditions. A second criticism is that many previous water footprint studies have assumed that crop water requirements have been fully met by supplementary irrigation, 20 which is rarely the case and leads to an overestimation of consumptive water use (Chapagain and Orr, 2009). In contrast, for this study, the supplementary irrigation used in each major growing region was based on government sponsored irrigation surveys and grower recommendations (Barraclough and Company, 1999; Ngo and Owens, 2002; DAFWA, 2003; NSW DPI, 2004; NT DPIFM, 2006; Johnson and Parr, 2007).

HESSD

$6,5085-5114,2009$

Consumptive water use associated with food waste

B. G. Ridoutt et al.

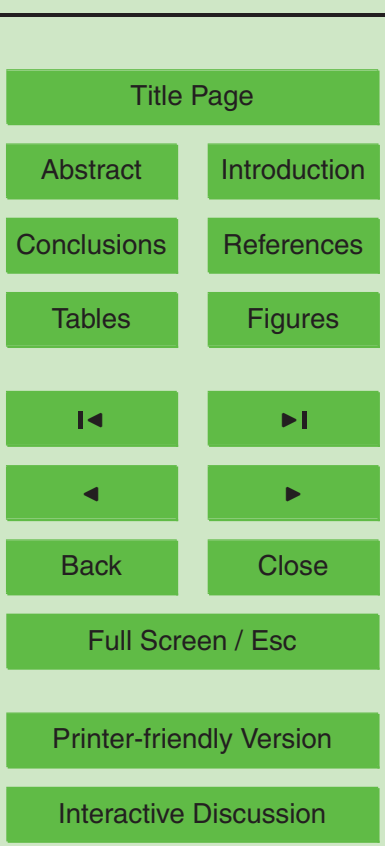




\subsection{Water footprint calculation}

The virtual water content (VWC) of a product is the sum of all the water consumed in the various stages of production. This usually includes so-called blue water appropriated from surface and groundwater resources, green water which is rainfall con5 sumed through crop evapotranspiration, and gray (or dilution) water, being the volume of freshwater needed to assimilate emissions to freshwater (Chapagain et al., 2006b). The VWC of Australian-grown fresh mango at the point of despatch from each major production region was calculated using average production statistics and the effective rainfall and supplementary irrigation data calculated above (Sect. 2.2). Gray

10 water requirements were calculated based on nitrogen application at $3 \mathrm{~kg} \mathrm{t}^{-1} \mathrm{ha}^{-1}$ of fruit yield, losses to freshwater of $30 \%$ (NSW DPI, 2004) and using the US EPA's recommended limit for nitrate in drinking water of $10 \mathrm{mgl}^{-1}$ (measured as nitrogen). In addition, $10 \mathrm{~m}^{3} \mathrm{ha}^{-1} \mathrm{yr}^{-1}$ of water was estimated to be used in orchard operations (weed and pest control, flowering management) and $0.7 \mathrm{~m}^{3}$ of water per $t$ of fruit in post 15 harvest operations (washing, application of fungicide and pesticide). Water use in the distribution and consumption stages of the product life cycle was considered to be negligible. For the purpose of apportioning water consumption between co-products, an economic allocation was used with $94 \%$ of the value of orchard production associated with the production of fresh mango and $6 \%$ with processing mangoes.

In the past, the water footprint of a product has been calculated in such a way that it is synonymous with the VWC (WFN, 2009). However, this approach to product water footprinting has been shown to be potentially misleading as it fails to differentiate adequately between irrigation water and natural rainfall that occurs over agricultural lands, despite the two having very different opportunity costs. In addition, there has generally been a failure to account for the local nature of freshwater scarcity (Ridoutt et al., 2009a, b). To report that the water footprint of a cup of coffee is $140 \mathrm{l}$ or the water footprint of one $\mathrm{kg}$ of cheese is $5000 \mathrm{I}$ (www.waterfootprint.org), gives no clear indication about the potential for harm from freshwater consumption. As such, the re-
HESSD

$6,5085-5114,2009$

Consumptive water use associated with food waste

B. G. Ridoutt et al.

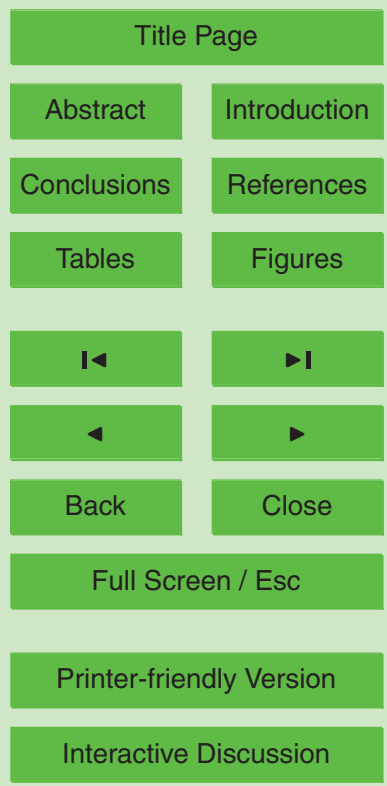


vised water footprint calculation method of Ridoutt and Pfister (2009; Fig. 1) was used in this study. This revised method considers freshwater consumption in the context of resource availability and enables quantitative comparisons between products and production stages in terms of their potential to contribute to freshwater scarcity. For 5 this method, the impact of land use on blue water resources was calculated using a comparison to a forested ecosystem using the method of Zhang et al. (2001). It was assumed that in the absence of production, the mango orchard would eventually revert to a forest or open woodland. Local water stress characterisation factors for each major mango producing region were derived from the water stress index (WSI) of Pfister et 10 al. (2009; Fig. 2). The WSI has a spatial resolution of 0.5 degrees and is more appropriate for describing water stress at a local watershed level than indicators based on national or per capita statistics.

\section{Results}

\subsection{Distribution and consumption waste}

15 Over the past six years, Australian mango growers have despatched an average of $44692 \mathrm{t}$ of fresh mango and $15260 \mathrm{t}$ of processing mango (Fig. 3). The latter represent mostly second grade mangoes, unmarketable as fresh fruit, which are used to make products such as juice and puree. Not all Australian mango growers are located in proximity to processing facilities, meaning that sale of the relatively low value processing fruit is often not viable. As such, considerable amounts of production waste are generated at the orchard stage, which we were unable to quantify. However, anecdotal evidence suggests that marketable fresh fruit may represent only around $40 \%$ of orchard production (AMIA, 2004), although this figure is certainly not representative of well managed orchards unless the harvest was damaged by severe weather conditions.

25 In Australia, mangoes are grown in the sub-tropical and tropical northern regions, requiring transportation over vast distances to the major urban centres of Sydney, Mel-
HESSD

$6,5085-5114,2009$

Consumptive water

use associated with food waste

B. G. Ridoutt et al.

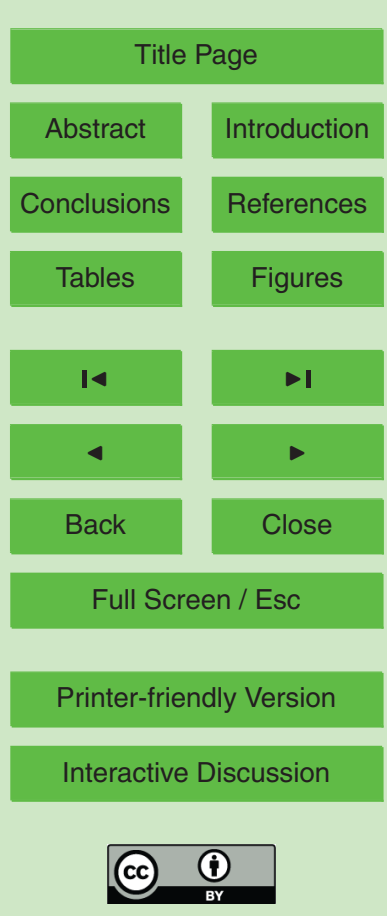


bourne and Brisbane. For example, the distance between the Mareeba growing region in Far North Queensland and Melbourne is around $2800 \mathrm{~km}$. The distance between the Katherine growing region and Sydney is around $3600 \mathrm{~km}$. The distribution channels for Australian fresh mango are also complex, potentially involving consolidators, 5 wholesalers and brokers and a range of chain store and independent retailers, the latter mainly fruit shops (CDI Pinnacle, 2004). Taking into account the minor levels of imported and exported fresh mango, fruit weight loss (i.e. respiration and moisture content losses) and sales to the consumer and food service sectors, waste in the distribution stage was estimated at $14709 \mathrm{t}$ (Fig. 3). Avoidable waste of fresh mango by

Australian households was estimated at $5642 \mathrm{t}$ (Fig. 3).

\subsection{Consumptive water use}

The consumptive use of green water, being equivalent to the effective rainfall, ranged from $5800 \mathrm{~m}^{3} \mathrm{ha}^{-1} \mathrm{yr}^{-1}$ in Kununurra to $12230 \mathrm{~m}^{3} \mathrm{ha}^{-1} \mathrm{yr}^{-1}$ in Northern New South Wales (Table 2; using the factor 10 to convert $\mathrm{mm} \mathrm{yr}^{-1}$ to $\mathrm{m}^{3} \mathrm{ha}^{-1} \mathrm{yr}^{-1}$ ). The consump15 tive use of blue water by supplementary irrigation ranged from 0 to $10600 \mathrm{~m}^{3} \mathrm{ha}^{-1} \mathrm{yr}^{-1}$ depending on the growing region and was always less than the irrigation requirement calculated by the CropWat model to ensure crop water requirements were always fully met (Table 2). For example, a benchmarking survey of horticultural producers in Queensland found that the average irrigation water use by mango growers in 20 the Mareeba district was $3700 \mathrm{~m}^{3} \mathrm{ha}^{-1} \mathrm{yr}^{-1}$ (Barraclough and Company, 1999, p. 51), equivalent to $370 \mathrm{~mm} \mathrm{yr}^{-1}$, and $327 \mathrm{~mm} \mathrm{yr}^{-1}$ or $47 \%$ lower than the calculated irrigation requirement (Table 2). In Northern New South Wales supplementary irrigation is not recommended, except in the orchard establishment phase (NSW DPI, 2004). Where supplementary irrigation is required, the critical time is during fruit development as wa25 ter stress at this time can lead to reduced yields (Johnson and Parr, 2007). At other times of the year, growers often limit irrigation to prevent excessive vegetative growth (Kulkarni and Landon-Lane, 1992).

Evapotranspiration by mango orchards consumed 50 to $81 \%$ of precipitation depend5094

\section{HESSD}

$6,5085-5114,2009$

Consumptive water use associated with food waste

B. G. Ridoutt et al.

Title Page

Abstract

Introduction

Conclusions

Tables

References

Figures

14

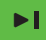

4

Back

Close

Full Screen / Esc

Printer-friendly Version

Interactive Discussion 
ing upon the growing region (Table 3). In contrast, the predicted evapotranspiration by forested ecosystems in these locations ranged from 61 to $89 \%$ of precipitation. As expected, the mango orchards intercepted less precipitation than the forested ecosystems they replaced (Scanlon et al., 2007; Rost et al., 2008). The exception was in

5 Northern New South Wales where a positive difference of $51 \mathrm{~mm} \mathrm{yr}^{-1}$ was predicted (Table 3), representing a consumptive use of freshwater due to reduced stream flow and/or groundwater recharge of $510 \mathrm{~m}^{3} \mathrm{ha}^{-1} \mathrm{yr}^{-1}$.

At orchard gate (i.e. the point of despatch to market after harvesting, washing, application of fungicides and insecticides, etc.), the total VWC of Australia's fresh mango 10 crop was $102.7 \mathrm{GI}$ (Table 4). The average proportions of green, blue and gray virtual water were 62,33 and $5 \%$, although this varied from one growing region to another. This represents the total volume of freshwater, from various sources, required to produce the average annual production of $44692 \mathrm{t}$ of fresh mango distributed across the major mango producing regions as described in Table 1. However, as described pre15 viously, not all of this consumptive water use has an impact on freshwater resource availability. The volumetric impact on blue water availability was $39.3 \mathrm{GI}$ and the water footprint, calculated using the water stress characterisation factors in Fig. 2, was $1.71 \mathrm{Gl}$ (Table 4). The greatest contribution to the water footprint came from the production of fresh mango in the Burdekin/Townsville growing region $(1.36 \mathrm{Gl}$ or approximately $80 \%$ of the industry's water footprint). What this means is that around $80 \%$ of the Australian fresh mango growing industry's potential to contribute to water scarcity occurred through the production of fresh mango in the Burdekin/Townsville region. Although this region produced only $23.2 \%$ of Australia's fresh mango (Table 1 ), it had the second highest water stress characterisation factor (0.110, Fig. 2) and the second highest irrigation water use (680 $\mathrm{mm} \mathrm{yr}^{-1}$, Table 2).

\subsection{Water footprint of mango food chain waste}

As a consequence of avoidable food chain waste and fruit weight loss, the consumption of one $\mathrm{kg}$ of fresh mango by an Australian household was estimated to require

HESSD

$6,5085-5114,2009$

Consumptive water use associated with food waste

B. G. Ridoutt et al.

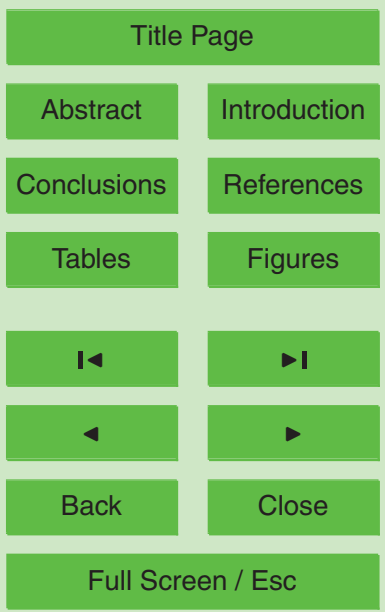

Printer-friendly Version

Interactive Discussion 
$1.36 \mathrm{~kg}$ to be purchased at the retail stage and $2.27 \mathrm{~kg}$ to be despatched from an orchard. As such, the VWC of one kg of Australian-grown fresh mango at the point of household consumption was 5218I, made up of 2429, 1921 and 867 I associated with the consumed fruit, distribution waste and consumer waste respectively (Table 5).

5 Similarly, the water footprint of Australian-grown fresh mango at the point of household consumption was $87 \mathrm{I} \mathrm{kg}^{-1}$, with $53 \%$ of the water footprint associated with distribution and consumption waste. The Australian-equivalent water footprint, derived by dividing the water footprint by the Australian average WSI (0.402) was $217 \mathrm{Ikg}^{-1}$, meaning that the consumption of one $\mathrm{kg}$ of fresh mango by an Australian household has the same o potential to contribute to freshwater scarcity as the direct consumption of 217 I of water in Australia.

Overall, waste in the food chain of Australian-grown fresh mango to Australian households represented an average annual waste of $26.7 \mathrm{Gl}$ of green water resources and $16.6 \mathrm{Gl}$ of blue water resources (Table 5). The water footprint of this waste was $0.72 \mathrm{Gl}$, comprising $0.50 \mathrm{Gl}$ for the distribution waste and $0.22 \mathrm{Gl}$ for the consumption waste. The corresponding Australian-equivalent water footprint of this waste was $1.80 \mathrm{Gl}$ (Table 5), meaning that consumptive water use associated with waste in the food chain of Australian-grown fresh mango to Australian households has the same potential to contribute to freshwater scarcity as the direct consumption of $1.80 \mathrm{Gl}$ of water in Australia.

\section{Discussion}

This study has provided further evidence to highlight the importance of food waste, with the finding that in the food chain of Australian-grown fresh mango to Australian households less than $50 \%$ of fruit despatched from the growing regions was ultimately consumed. Most important were the losses occurring in the distribution stage, esti-

mated at almost $37 \%$ of fruit. Mangoes, which are an extremely perishable fruit, require careful postharvest handling, including temperature and disease control, to achieve acceptable retail shelf life, consistent ripening and good quality retail presentation. Poor

\section{HESSD}

$6,5085-5114,2009$

Consumptive water use associated with food waste

B. G. Ridoutt et al.

Title Page

Abstract

Introduction

Conclusions

Tables

References

Figures

14

$\rightarrow 1$

4

Back

Close

Full Screen / Esc

Printer-friendly Version

Interactive Discussion 
practices can lead to entire consignments becoming unsalable by the time they reach the retailer (Ledger at al., 2003). As such, efforts are underway within the Australian mango industry to improve fruit transportation and ripening systems (Hennessy, 2008).

Avoidable losses occurring in the consumption stage were estimated at almost $17 \%$ 5 of fruit, based on statistics from the UK (WRAP, 2008) which were deemed to be relevant to mango consumption in Australia. On the one hand, mango is more perishable than many other kinds of common fruits, such as apples and oranges, meaning that consumer wastage of mango is likely to be higher than the average. However, in Australia, mango is a special occasion fruit, usually consumed at home (McKinna, 2005), 10 and therefore perhaps less likely to be wasted than fruits purchased routinely, in larger quantities, and carried outside the home (e.g. in packed lunches). Further research is needed in Australia to more accurately define the composition of food waste, the causal factors and opportunities for reduction and diversion.

In Australia, very little waste in the mango food chain is likely to be recovered for other beneficial purposes such as reprocessing and redistribution through charitable organisations, compositing or bioenergy production (Morgan, 2009). Welfare agencies have only recently begun to collect unsalable fresh fruit, vegetables and meat from supermarkets and this is occurring only on a limited scale (Godinho, 2009). Compared to the $65000 \mathrm{t}$ of organic waste sent to landfill by Woolworths, one of Australia's two largest supermarket chains, the company diverted only $5354 \mathrm{t}$ for renewable energy production in the 2007/08 financial year (Woolworths Limited, 2008).

Food chain waste has important implications for virtual water accounting. In this study, the VWC of one kg of Australian-grown fresh mango consumed by an Australian household increased from 2429 to $5218 \mathrm{I}$ when distribution and consumption waste were taken into consideration, which is more than a doubling (Table 5). These numbers compare with $3156 \mathrm{I} \mathrm{kg}^{-1}$ reported in the often cited UNESCO-IHE report: Water Footprints of Nations (Chapagain and Hoekstra, 2004). However, as mentioned previously, these VWC values have the potential to be misleading because they fail to differentiate the source of the water used and the local water scarcity. Therefore, these
HESSD

6, 5085-5114, 2009

Consumptive water use associated with food waste

B. G. Ridoutt et al.

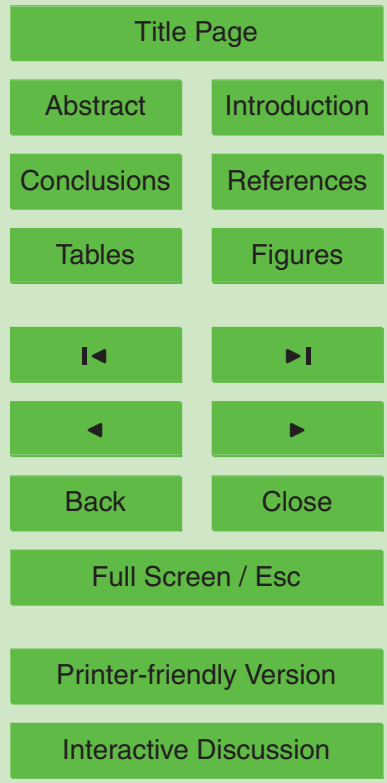


figures give no indication of the potential to cause harm from consumptive water use. As such, the water footprint calculation method of Ridoutt and Pfister (2009) was used, as it enables a quantitative comparison between products in terms of their potential to contribute to water scarcity. The water footprint of one $\mathrm{kg}$ of Australian-grown mango 5 consumed by an Australian household was 87I (Table 5), which compares to 141 I for a jar of Dolmio $®$ pasta sauce $(575 \mathrm{~g})$ and 13 I for a bag of Peanut M\&M's $®(250 \mathrm{~g}$; Ridoutt and Pfister, 2009).

The impact of mango production on water resources also varied regionally. This was evident when water footprint values were compared, as they ranged from $7.5 \mathrm{Igg}^{-1}$ 10 (at orchard gate for the Mareeba growing region) to $132 \mathrm{I} \mathrm{kg}^{-1}$ (Burdekin/Townsville growing region), which is almost an 18-fold difference in the potential to contribute to water scarcity. As such, efforts to improve water use efficiency in mango orchards would deliver the greatest benefits if first targeted to the Burdekin/Townsville region. However, variability in water use efficiency between individual growers, which is also understood to be high (Growcom, 2004), would also need to be taken into account.

From a global perspective, one of the greatest challenges is to meet future food demands within the constraints of sustainable freshwater consumption. The enormity of this challenge arises from the fact that freshwater has already become a scarce and overexploited natural resource in many parts of the world, including parts of Australia.

At a practical level, the impact of food consumption patterns on global freshwater resources must become less intense. Product water footprints, which describe the potential of a product to contribute to water scarcity, must therefore be progressively reduced. In this regard, we have considered the likely effectiveness of food chain waste reduction as a strategy for reducing product water footprints and a comparison was made with other potential measures.

In a scenario where distribution and consumption waste were each halved, the water footprint of one $\mathrm{kg}$ of Australian-grown fresh mango consumed by an Australian household would be reduced from 87 to $57 \mathrm{I}$, which is a reduction of $34 \%$. Similarly, the Australian-equivalent water footprint would be reduced from 217 to $142 \mathrm{I}$, a sav-

HESSD

6, 5085-5114, 2009

Consumptive water use associated with food waste

B. G. Ridoutt et al.

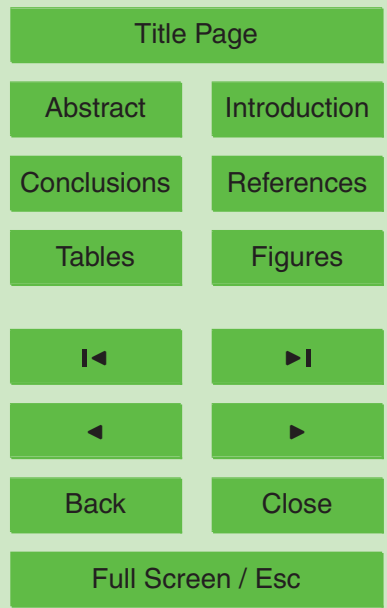

Printer-friendly Version

Interactive Discussion 
ing equivalent to $74 \mathrm{I}$ of direct water consumption for every one $\mathrm{kg}$ of fresh mango consumed. In comparison, a detailed benchmarking study of irrigation water use in Queensland identified a gap of $40 \%$ between best water use efficiency in mango orchards and average practice (Barraclough and Company, 1999). In a second sce-

5 nario where irrigation water use was reduced by $40 \%$ across half of Australia's mango orchard estate (while maintaining the same yields), the water footprint of one $\mathrm{kg}$ of Australian-grown fresh mango consumed by an Australian household would be reduced from 87 to $72 \mathrm{I}$, which is a reduction of $18 \%$. This saving would be equivalent to $38 \mathrm{I}$ of direct water use for every one $\mathrm{kg}$ of fresh mango consumed. Since the

10 Australian mango industry is in a growth phase (AMIA, 2004), another strategy might involve deliberate expansion in regions where freshwater is most abundant and where irrigation water use will have the least potential to contribute to water scarcity. In a third scenario where the industry expanded by $20 \%$ with that growth occurring in the Darwin and Katherine regions (WSI 0.010, Fig. 2), the average water footprint of one $15 \mathrm{~kg}$ of Australian-grown fresh mango consumed by an Australian household would be reduced from 87 to 77 I, or $11 \%$.

These three scenarios are admittedly simplistic and deserve further careful consideration and analysis. However, they do serve to confirm that reducing food chain waste is an important strategy for alleviating the pressure of food consumption on freshwater resources. Interventions to reduce food chain waste will likely have as great or even greater impact on freshwater resource availability as other possible strategies, such as improving irrigation water use efficiency. Hence, an escalation in efforts to reduce food chain waste is essential.

\section{Conclusions}

25 The point has been well made that food waste is also a waste of precious water resources (Lundqvist et al., 2008; Nellemann et al., 2009). However, until a link is established between specific waste streams and the local water resources that are be-

HESSD

$6,5085-5114,2009$

Consumptive water use associated with food waste

B. G. Ridoutt et al

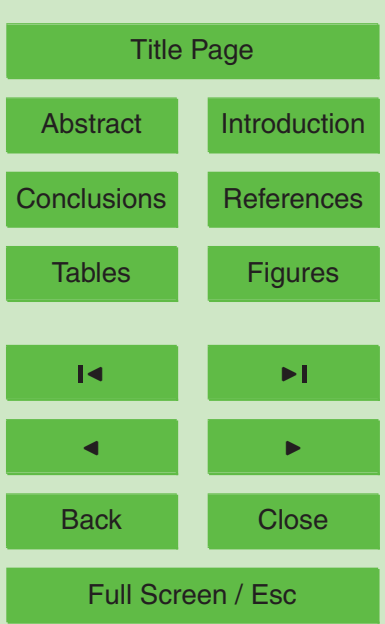

Printer-friendly Version

Interactive Discussion 
ing adversely impacted there is little empowerment for action. While water resources can be discussed in terms of national or global averages, the consequences of water scarcity, being resource depletion and damage to human health and ecosystem quality (Pfister et al., 2009; Ridoutt et al., 2009b), are experienced at the local watershed level.

5 What this case study of the mango food chain in Australia has shown is that product water footprinting can be used to make this waste of water transparent and meaningful in the context of local water resource availability. This transparency is critical if food waste is to be seen not simply in terms of its private economic cost, but in terms of the wider social and environmental impacts, and thereby create a case for government 10 intervention as well as corporate and personal action on the grounds of social responsibility. A further complication is the increasing connectedness of global food chains, meaning that water resource impacts may occur far from where consumption and food chain waste is occurring. We therefore concur with Chapagain and Orr $(2009$, p. 1227) who argue that, "The local character of a product's virtual water content must be made 15 more transparent through the supply chain in order to better understand the impacts of distant consumption on local water resources" (emphasis added). At present, the extent to which the local consumption and waste of food products is intervening in the hydrological cycle throughout the world is rarely understood or appreciated.

Traditionally, water resources planning and management has focussed on increasing 20 supply and where supply has become limited the shift has been to demand management, usually in relation to direct consumption by the industrial, domestic and agricultural sectors. In future, these efforts need to be complemented by strategies which take into consideration indirect (or virtual) water consumption. At the consumer level, indirect water use through the consumption of food and other goods and services is 25 far greater than direct water use, representing perhaps $90 \%$ of an individual's burden on freshwater resources (Molden et al., 2007). Ultimately, it is the demand for goods and services that creates the demand for consumptive water use in the industrial and agricultural sectors.

Food waste is ubiquitous, occurring at all stages of the food chain. Therefore, a large

\section{HESSD}

$6,5085-5114,2009$

\section{Consumptive water use associated with food waste}

B. G. Ridoutt et al.

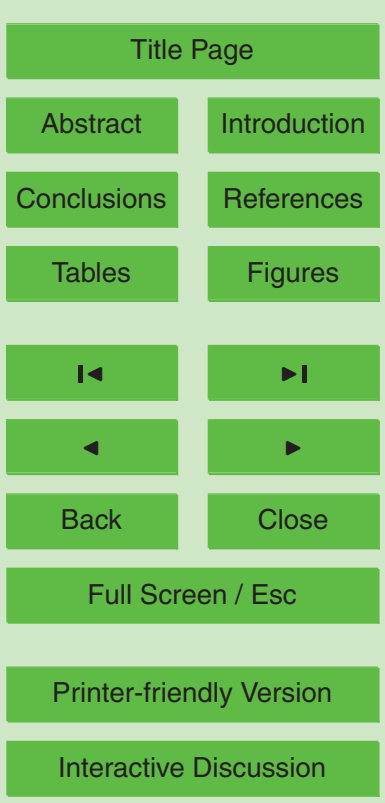


and diverse group of stakeholders need to be made aware of the consequences of food waste on water resources and subsequently engaged in efforts to reduce food chain waste. Overcoming the social, political and technological barriers which cause food chain waste to persist will be important. In order to address the unsustainable use of global freshwater resources and meet the food production requirements of a growing world population, food chains must become much more efficient in terms of consumptive water use. For the Australian mango food chain, our analysis indicated that reducing waste was indeed an effective way of reducing impacts on freshwater resources relative to other water efficiency measures. However, this conclusion might vary from 10 one food chain to another and a widespread adoption of product water footprinting by the agriculture and food industries is encouraged to underpin priority setting.

Acknowledgements. We sincerely thank Trevor Dunmall (Australian Mango Industry Association), Wayne Prowse (Horticulture Australia Limited) and David McKinna (McKinna et al Pty Ltd) who each provided helpful insights into the Australian mango industry. We also thank two CSIRO internal reviewers, Joely Taylor and Paul Koltun.

\section{References}

AMIA (Australian Mango Industry Association): Mango Industry Strategic Plan, online available at: http://www.horticulture.com.au/librarymanager/libs/45/Mango\%20Strategic\%20Plan.pdf, (last access: May 2009), 2004.

Barraclough \& Co.: Audit of water \& irrigation use efficiencies on farms within the Queensland horticultural industry, online available at: http://www.nrw.qld.gov.au/services_resources/item details.php?item_id=31059, (last access: May 2009), 1999.

Bally, I. S. E., Johnson, P. R., and Kulkarni, V. J.: Mango production in Australia, Acta Hortic., 509, 59-67, 2000.

25 Bartram, J.: Improving on haves and have-nots, Nature, 452, 7185, 283-284, 2008.

Bloom, J.: The food not eaten. Food waste: out of sight, out of mind, Culinate, Portland, OR, USA, online available at: http://www.culinate.com/articles/features/wasted_food, (last access: May 2009), 2007.

\section{HESSD}

$6,5085-5114,2009$

\section{Consumptive water use associated with food waste}

B. G. Ridoutt et al.

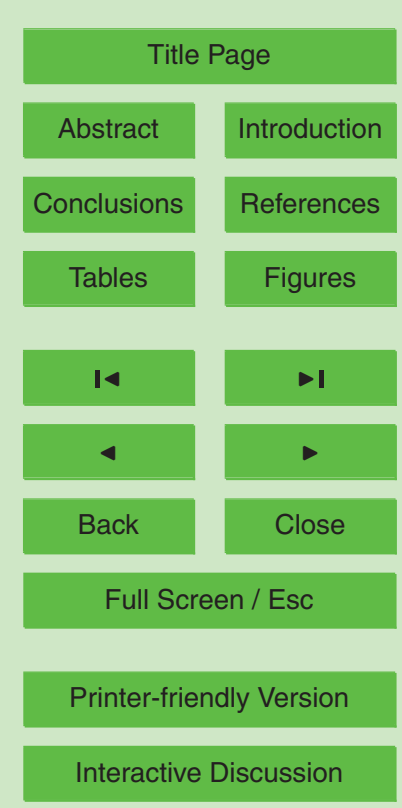

Interactive Discussion 
CDI Pinnacle: Horticulture value chain analysis and policy development, online available at: http://www.growcom.com.au/_uploads/16348Submission_Horticultural_Value_Chain_ Analysis.pdf, (last access: May 2009), 2004.

Chapagain, A. K., and Hoekstra, A. Y.: Water footprints of nations, Value of Water Research Report Series No.16, UNESCO-IHE, Delft, The Netherlands, 2004.

Chapagain, A. K., Hoekstra, A. Y., and Savenije, H. H. G.: Water saving through international trade of agricultural products, Hydrol. Earth Syst. Sci., 10, 455-468, 2006a, http://www.hydrol-earth-syst-sci.net/10/455/2006/.

Chapagain, A. K., Hoekstra, A. Y., Savenije, H. H. G., and Gautam, R.: The water footprint of cotton consumption: An assessment of the impact of worldwide consumption of cotton products on the water resources in the cotton producing countries, Ecol. Econ., 60(1), 186203, 2006b.

Chapagain, A. K. and Orr, S.: An improved water footprint methodology linking global consumption to local water resources: A case study of Spanish tomatoes, J. Environ. Manage., 15 90(2), 1219-1228, 2009.

DAFWA (Department of Agriculture and Food Western Australia): Irrigation Calculator, ver. 4.0, online available at: http://www.agric.wa.gov.au/content/lwe/water/irrig_calculator_nlantzke. htm, (last access: May 2009), 2003.

Environmental Leader: Foodservice firm buys less beef, cheese, tropical fruit to cut carbon impact, online available at: http://www.environmentalleader.com/2009/04/06/ foodservice-firm-buys-less-beef-cheese-tropical-fruit-to-cut-carbon-impact/, (last access: May 2009), 2009.

Falkenmark, M.: Water and sustainability: A reappraisal, Environment, 50(2), 4-16, 2008.

Falkenmark, M. and Lannerstad, M.: Consumptive water use to feed humanity - curing a blind spot, Hydrol. Earth Syst. Sci., 9, 15-28, 2005, http://www.hydrol-earth-syst-sci.net/9/15/2005/.

FAO: CropWat for Windows, version 4.3, online available at: http://www.fao.org/nr/water/ infores_databases_cropwat.html, (last access: May 2009), 1998.

FAO: Medium-term prospects for agricultural commodities, online available at: http://www.fao. org/docrep/006/y5143e/y5143e00.htm, (last access: May 2009), 2003.

FAO: New_LocClim Local Climate Estimator, online available at: http://www.fao.org/nr/climpag/ pub/en3_051002_en.asp, (last access: May 2009), 2005.

FAO: Number of hungry people rises to 963 million, online available at: http://www.fao.org/

\section{2}

\section{HESSD}

$6,5085-5114,2009$

\section{Consumptive water use associated with food waste}

B. G. Ridoutt et al.

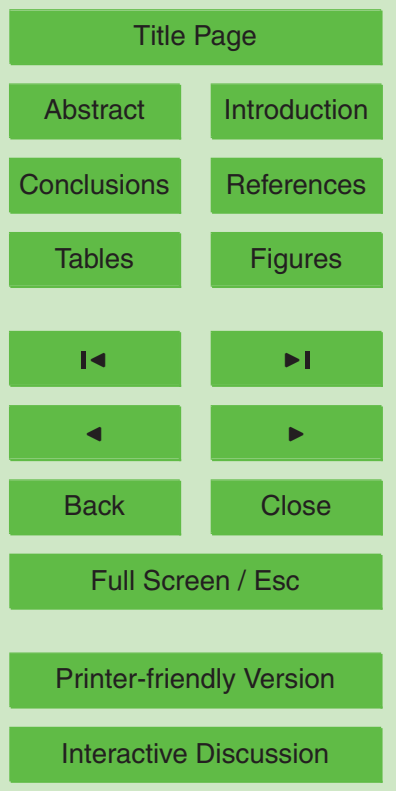


news/story/en/item/8836/, (last access: May 2009), 2008a.

FAO: The state of food insecurity in the world, online available at: http://www.fao.org/docrep/ 011/i0291e/i0291e00.htm, (last access: May 2009), 2008b.

Godinho, M.: Let's waste not while others are wanting, in: The Age, Melbourne, Australia, 1 May 2009.

Growcom: Benchmark - irrigating mangoes, Water for Profit Fact Sheet, Growcom, Fortitude Valley, Queensland, Australia, 2004.

Hennessy, C.: Implementing a top end better mangoes project, in: Mango Industry Report 07/08, Australian Mango Industry Association, Mareeba, Australia, 2008.

10 Henningsson, S., Hyde, K., Smith, A., and Campbell, M.: The value of resource efficiency in the food industry: A waste minimisation project in East Anglia, UK, J. Clean Prod., 12(5), 505-512, 2004.

Johnson, P. R. and Parr, D.: Mango growing in Western Australia, online available at: http://www.agric.wa.gov.au/content/hort/fn/cp/pawpaws/b4348_index.htm, (last access: May 2009), 2007.

Kader, A. A.: Increasing food availability by reducing postharvest losses of fresh produce, Acta Hortic., 682, 2169-2175, 2005.

Kulkarni, V. J. and Landon-Lane, C.: Report on mango growers' survey, Technical Bulletin 183, Northern Territory Department of Primary Industries and Fisheries, Darwin, Australia, 1992.

Lebel, L. and Lorek, S.: Enabling sustainable production-consumption systems, Ann. Rev. Environ. Resour., 33, 241-275, 2008.

Ledger, S. N., Campbell, T. P., Holmes, R. J., Kernot, I. I., and Hofman, P. J.: Improving knowledge and practices in mango supply chains, in: Proceedings of the Australian Postharvest Horticulture Conference, Brisbane, Australia, 1-3 October, 2003, 77-79, 2003.

Liu, J. and Savenije, H. H. G.: Food consumption patterns and their effect on water requirement in China, Hydrol. Earth Syst. Sci., 12, 887-898, 2008,

http://www.hydrol-earth-syst-sci.net/12/887/2008/.

Liu, J. G., Yang, H., and Savenije, H. H. G.: China's move to higher-meat diet hits water security, Nature, 454, 7203, p. 397, 2008.

30 Liu, J. G., Zehnder, A. J. B., and Yang, H.: Global consumptive water use for crop production: The importance of green water and virtual water, Water Resour. Res., 45, W05428, doi:10.1029/2007WR006051, 2009.

Liu, J. G., Zehnder, A. J. B., and Yang, H.: Historical trends in China's virtual water trade, Water
HESSD

$6,5085-5114,2009$

\section{Consumptive water use associated with food waste}

B. G. Ridoutt et al.

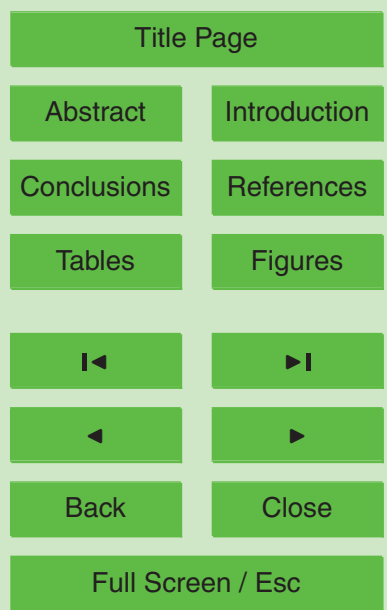

Printer-friendly Version

Interactive Discussion 
Int., 32(1), 78-90, 2007.

Lundqvist, J., Barron, J., Berndes, G., Berntell, A., Falkenmark, M., Karlberg, L., and Rockström, J.: Water pressure and increases in food \& bioenergy demand implications of economic growth and options for decoupling, in: Scenarios on Economic Growth and Resource

5 Demand, Swedish Environmental Advisory Council, Ministry of the Environment, Stockholm, Sweden, 2007.

Lundqvist, J., de Fraiture, C., and Molden, D.: Saving water: From field to fork, SIWI Policy Brief, Stockholm International Water Institute, Stockholm, Sweden, 2008.

Macnish, A. J., Joyce, D. C., and Hetherington, S. E.: Packaging to reduce water loss can delay ripening of mango (Mangifera indica L. cv. "Kensington Pride") fruit, Aust. J. Exp. Agr., 37(4), 463-467, 1997.

McKinna, D.: Australian mango industry: Consumer market research, usage \& attitude, purchasing \& consumption, Horticulture Australia Limited, Sydney, Australia, 2005.

Meeusen, M. and Hagelaar, G.: Food losses: what do stakeholders think? A study of per15 ception, attitude and behaviour of stakeholders to prevent food losses, Report 2008-014, Landbouw-Economisch Instituut, Den Haag, The Netherlands, 2008.

Molden, D., de Fraiture, C., and Rijsberman, F.: Water scarcity: The food factor, Issues Sci. Technol., 23(4), 39-48, 2007.

Morgan, E.: Fruit and vegetable consumption and waste in Australia, Victorian Health Promotion Foundation, Carlton South, Australia, 2009.

Nellemann, C., MacDevette, M., Manders, T., Eickhout, B., Svihus, B., Prins, A. G., and Kaltenborn, B. P. (Eds.): The environmental food crisis: The environment's role in averting future food crises, UNEP rapid response assessment, United Nations Environment Programme, UNEP/GRID-Arendal, Arendal, Norway, 2009.

NSW DPI (New South Wales Department of Primary Industries): Mango Growing. Agfact H6.1.10, fourth edition, NSW Centre for Tropical Horticulture, Alstonville, Australia, 2004.

Ngo, H. and Owens, G.: The profitability of mangoes in the top end, Technical Bulletin 301, Northern Territory Government Department of Business, Industry \& Resource Development, Darwin, Australia, 2002.

30 NT DPIFM (Northern Territory Department of Primary Industry, Fisheries and Mines): Growing Note FG8 - Mango, online available at: http://www.nt.gov.au/d/Content/File/p/Fruit/ FG8_mango.pdf, (last access: May 2009), 2006.

Pagan, B. and Prasad, P.: The Queensland food eco-efficiency project: Reducing risk and

\section{HESSD}

6, 5085-5114, 2009

\section{Consumptive water use associated with food waste}

B. G. Ridoutt et al.

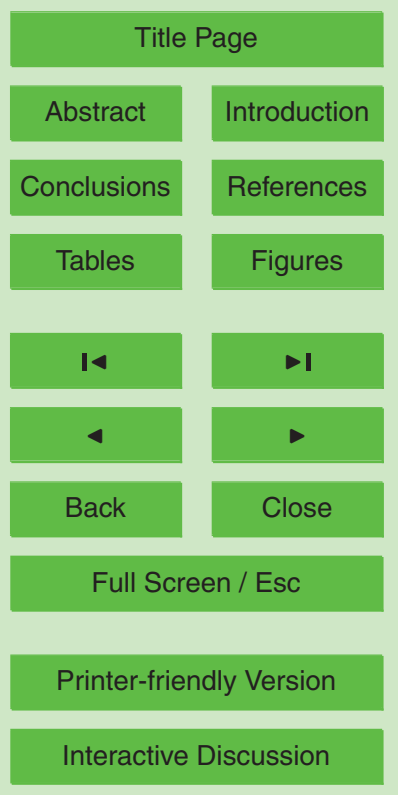


improving competitiveness, J. Clean Prod., 15(8-9), 764-771, 2007.

Pfister, S., Koehler, A., and Hellweg, S.: Assessing the environmental impacts of freshwater consumption in LCA, Environ. Sci. Technol., 43(11), 4098-4104, 2009.

Ridoutt, B. G., Eady, S. J., Sellahewa, J., Simons, L., and Bektash, R.: Water footprinting at the 5 product brand level: case study and future challenges, J. Clean Prod., 17(13), 1228-1235, 2009a.

Ridoutt, B. G., Eady, S. J., Sellahewa, J., Simons, L., and Bektash, R.: Product water footprinting: How transferable are the concepts from carbon footprinting? In: Proceedings of the 6th Australian Conference on Life Cycle Assessment: Sustainability Tools for a New Climate, Melbourne, Australia, 16-19 February 2009b.

Ridoutt, B. G. and Pfister, S.: A new approach to water footprinting to make transparent the impacts of consumption and production on global freshwater scarcity, Global Environ. Chang., in review, 2009.

Rockström, J.: Water for food and nature in drought-prone tropics: Vapour shift in rain-fed 15 agriculture, Philos. T. Roy. Soc. B, 358, 1440, 1997-2009, 2003.

Rockström, J. and Barron, J.: Water productivity in rainfed systems: Overview of challenges and analysis of opportunities in water scarcity prone savannahs, Irrigation Sci., 25(3), 299311, 2007.

Rockström, J., Falkenmark, M., Karlberg, L., Hoff, H., Rost, S., and Gerten, D.: Future water availability for global food production: The potential of green water for increasing resilience to global change, Water Resour. Res., 45, W00A12, doi:10.1029/2007WR006767, 2009.

Rockström, J., Lannerstad, M., and Falkenmark, M.: Assessing the water challenge of a new green revolution in developing countries, P. Natl. Acad. Sci. USA, 104(15), 6253-6260, 2007.

Rost, S., Gerten, D., and Heyder, U.: Human alterations of the terrestrial water cycle through land management, Adv. Geosci., 18, 43-50, 2008, http://www.adv-geosci.net/18/43/2008/.

Scanlon, B. R., Jolly, I., Sophocleous, M., and Zhang, L.: Global impacts of conversions from natural to agricultural ecosystems on water resources: Quantity versus quality, Water Resour. Res., 43(3), WO3437, doi:10.1029/2006WR005486, 2007.

30 UNESCO-WWAP: Water: A Shared Responsibility: The United Nations World Water Development Report 2, United Nations Educational Scientific and Cultural Organization-World Water Assessment Programme, Paris, France, 2006.

WFN (Water Footprint Network): Glossary - Water Footprint, online available at: www.

\section{HESSD}

$6,5085-5114,2009$

\section{Consumptive water use associated with food waste}

B. G. Ridoutt et al.

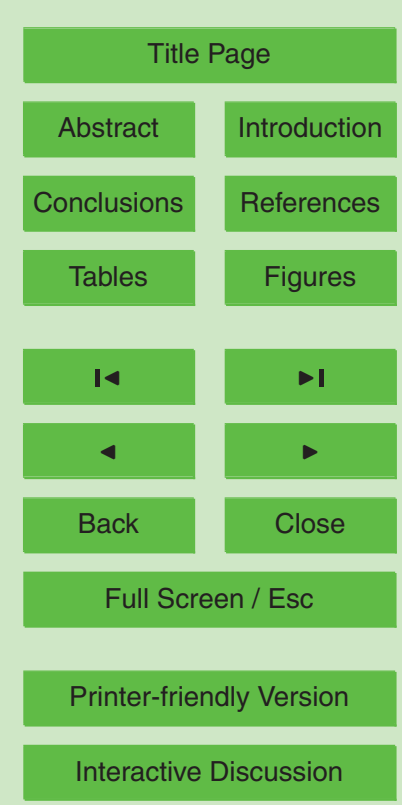


waterfootprint.org/?page=files/DefinitionWaterFootprint, (last access: Feburary 2009), 2009.

Woolworths Limited: Corporate Responsibility Report 2008, online available at: http: //crreport08.woolworthslimited.com.au/about_woolworths.php, (last access: May 2009), 52008

WRAP (Waste and Resources Action Programme): The Food We Waste, online available at: http://www.wrap.org.uk/downloads/The_Food_We_Waste_v2_2_.3e1bd9e2.5635. pdf, (last access: May 2009), 2008.

Yang, H., Wang, L., Abbaspour, K. C., and Zehnder, A. J. B.: Virtual water trade: an assessment of water use efficiency in the international food trade, Hydrol. Earth Syst. Sci., 10, 443-454, 2006,

http://www.hydrol-earth-syst-sci.net/10/443/2006/.

Yang, H. and Zehnder, A.: "Virtual water": An unfolding concept in integrated water resources management, Water Resour. Res., 43, W12301, doi:10.1029/2007WR006048, 2007.

15 Zhang, L., Dawes, W. R., and Walker, G. R.: Response of mean evapotranspiration to vegetation changes at catchment scale, Water Resour. Res., 37(3), 701-708, 2001.

HESSD

$6,5085-5114,2009$

Consumptive water use associated with food waste

B. G. Ridoutt et al.

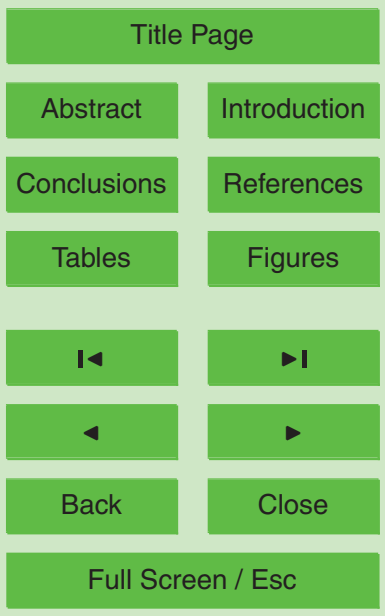

Printer-friendly Version

Interactive Discussion 


\section{HESSD}

$6,5085-5114,2009$

\section{Consumptive water} use associated with food waste

Table 1. Major mango producing regions in Australia.

\begin{tabular}{lrr}
\hline Region & $\begin{array}{r}\text { Production } \\
\left(\mathrm{t} \mathrm{yr}^{-1}\right)^{\mathrm{a}}\end{array}$ & $\%$ \\
\hline Burdekin/Townsville, Queensland & 12737 & 23.2 \\
Mareeba, Queensland & 18563 & 33.8 \\
Bundaberg, Queensland & 2100 & 3.8 \\
Northern New South Wales & 800 & 1.5 \\
Darwin, Northern Territory & 12792 & 23.3 \\
Katherine, Northern Territory & 6430 & 11.7 \\
Kununurra, Western Australia & 1470 & 2.7 \\
Total & 54893 & 100 \\
\hline
\end{tabular}

B. G. Ridoutt et al.

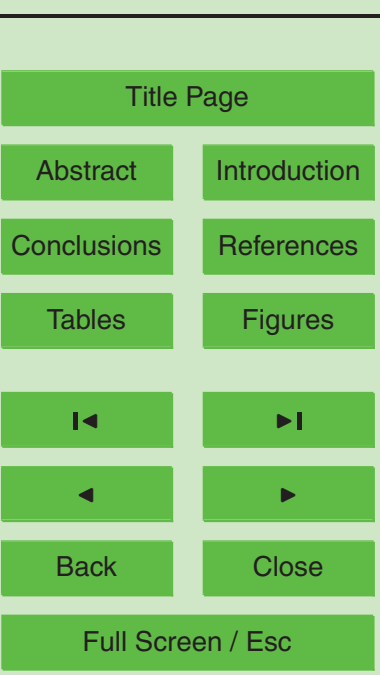

Printer-friendly Version

a Based on 2004/05 season. Source: Australian Mango Industry Association and Northern Territory Government, Department of Regional Development, Primary Industry, Fisheries and Resources.

Interactive Discussion 


\section{HESSD}

$6,5085-5114,2009$

\section{Consumptive water use associated with food waste}

Table 2. Crop water requirements for Australian mango.

\begin{tabular}{lrrrr}
\hline Region & $\begin{array}{r}\text { Crop water } \\
\text { requirement } \\
\left(\mathrm{mm} \mathrm{yr}^{-1}\right)^{\mathrm{a}}\end{array}$ & $\begin{array}{r}\text { Effective } \\
\text { rainfall } \\
\left(\mathrm{mm} \mathrm{yr}^{-1}\right)^{\mathrm{a}}\end{array}$ & $\begin{array}{r}\text { Irrigation } \\
\text { requirement } \\
\left(\mathrm{mm} \mathrm{yr}^{-1}\right)^{\mathrm{a}}\end{array}$ & $\begin{array}{r}\text { Recommended } \\
\text { irrigation } \\
\left(\mathrm{mm} \mathrm{yr}^{-1}\right)^{\mathrm{b}}\end{array}$ \\
\hline Burdekin/Townsville, Queensland & 1679 & 765 & 914 & 680 \\
Mareeba, Queensland & 1664 & 1053 & 697 & 370 \\
Bundaberg, Queensland & 1570 & 866 & 703 & 400 \\
Northern New South Wales & 1288 & 1223 & 215 & 0 \\
Darwin, Northern Territory & 1989 & 915 & 1142 & 438 \\
Katherine, Northern Territory & 1932 & 671 & 1266 & 438 \\
Kununurra, Western Australia & 2045 & 580 & 1466 & 1060 \\
\hline
\end{tabular}

B. G. Ridoutt et al.

${ }^{a}$ CropWat for Windows ver. 4.3 (FAO, 1998);

b Source: Barraclough and Co (1999), Ngo and Owens (2002), DAFWA (2003), NSW DPI (2004), NT DPIFM (2006), Johnson and Parr (2007).

Title Page

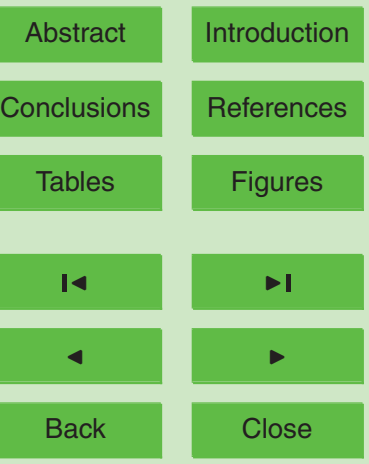

Full Screen / Esc

Printer-friendly Version

Interactive Discussion 


\section{HESSD}

$6,5085-5114,2009$

Table 3. Impact of land use on blue water resources: comparison of mango growing with a forest ecosystem.

\begin{tabular}{lrrrrrr}
\hline & \multicolumn{5}{c}{ Mango } & Forest \\
\cline { 3 - 6 } Region & $\begin{array}{r}\text { Precipitation } \\
(\mathrm{mm})^{\mathrm{a}}\end{array}$ & $\begin{array}{r}\text { Effective } \\
\text { rainfall } \\
(\mathrm{mm})^{\mathrm{b}}\end{array}$ & $\begin{array}{r}\text { Loss } \\
(\%)\end{array}$ & $\begin{array}{r}\text { ET } \\
(\mathrm{mm})^{\mathrm{c}}\end{array}$ & $\begin{array}{r}\text { Loss } \\
(\%)\end{array}$ & $\begin{array}{r}\text { Difference } \\
(\mathrm{mm})\end{array}$ \\
\hline Burdekin/Townsville, Queensland & 1040 & 765 & 74 & 867 & 83 & -102 \\
Mareeba, Queensland & 2123 & 1053 & 50 & 1289 & 61 & -236 \\
Bundaberg, Queensland & 1069 & 866 & 81 & 885 & 83 & -18 \\
Northern New South Wales & 1708 & 1223 & 72 & 1172 & 69 & 51 \\
Darwin, Northern Territory & 1684 & 915 & 54 & 1164 & 69 & -249 \\
Katherine, Northern Territory & 956 & 671 & 70 & 816 & 85 & -145 \\
Kununurra, Western Australia & 778 & 580 & 75 & 695 & 89 & -115 \\
\hline
\end{tabular}

${ }^{a}$ New_LocClim Local Climate Estimator (FAO, 2005);

${ }^{b}$ CropWat for Windows ver. 4.3 (FAO, 1998);

${ }^{\mathrm{c}}$ Evapotranspiration (ET) for a forested ecosystem calculated using the method of Zhang et al. (2001).

\section{Consumptive water use associated with food waste}

B. G. Ridoutt et al.

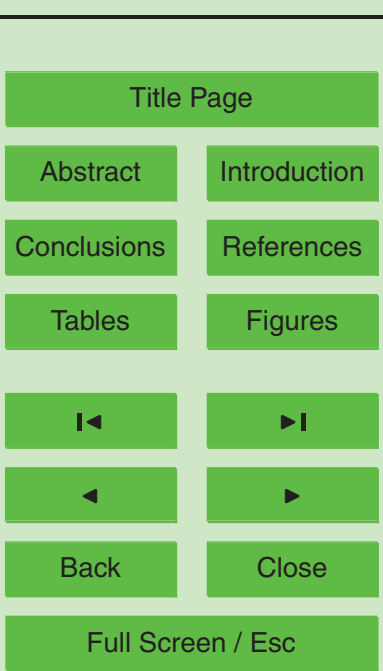

Printer-friendly Version

Interactive Discussion 


\section{HESSD}

$6,5085-5114,2009$

\section{Consumptive water use associated with food waste}

Table 4. Virtual water content (VWC, Gl) of Australian mango production (at orchard gate) based on an average annual production of $44692 t$ distributed across the major mango producing regions as described in Table 1 . The land use impact, blue water impact and water footprint (WF, all Gl) were calculated following the method of Ridoutt and Pfister (2009). The water footprint calculation uses the Water Stress Index (WSI) of Pfister et al. (2009; Fig. 2).

\begin{tabular}{lrrrrrrr}
\hline Region & $\begin{array}{r}\text { Green } \\
\text { VWC }\end{array}$ & $\begin{array}{r}\text { Blue } \\
\text { VWC }\end{array}$ & $\begin{array}{r}\text { Gray } \\
\text { VWC }\end{array}$ & $\begin{array}{r}\text { Total } \\
\text { VWC }\end{array}$ & $\begin{array}{r}\text { Land use } \\
\text { impact }\end{array}$ & $\begin{array}{r}\text { Blue water } \\
\text { impact }\end{array}$ & WF \\
\hline Burdekin/Townsville, Queensland & 12.6 & 11.2 & 1.2 & 25.0 & 0 & 12.4 & 1.36 \\
Mareeba, Queensland & 25.3 & 8.9 & 1.7 & 36.0 & 0 & 10.6 & 0.11 \\
Bundaberg, Queensland & 2.4 & 1.1 & 0.2 & 3.6 & 0 & 1.3 & 0.016 \\
Northern New South Wales & 1.3 & $<0.1$ & $<0.1$ & 1.3 & $<0.1$ & 0.1 & 0.014 \\
Darwin, Northern Territory & 15.2 & 7.3 & 1.2 & 23.6 & 0 & 8.5 & 0.086 \\
Katherine, Northern Territory & 5.6 & 3.7 & 0.6 & 9.8 & 0 & 4.3 & 0.043 \\
Kununurra, Western Australia & 1.1 & 2.0 & 0.1 & 3.3 & 0 & 2.1 & 0.076 \\
Total Australian production & 63.4 & 34.2 & 5.1 & 102.7 & $<0.1$ & 39.3 & 1.71 \\
\hline
\end{tabular}

B. G. Ridoutt et al.

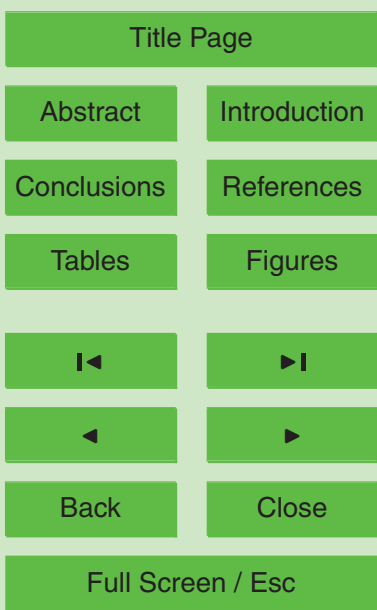

Printer-friendly Version

Interactive Discussion 


\section{HESSD}

$6,5085-5114,2009$

\section{Consumptive water use associated with food waste}

Table 5. Virtual water content (VWC), blue water impact, water footprint (WF) and Australianequivalent water footprint of Australian grown fresh mango consumed by Australian households.

\begin{tabular}{lrrrrrrrr}
\hline & \multicolumn{3}{l}{$\begin{array}{l}\text { One kg of Australian-grown } \\
\text { fresh mango consumed by an } \\
\text { Australian household }\end{array}$} & \multicolumn{5}{l}{$\begin{array}{l}\text { Annual consumption of } \\
\text { Australian-grown fresh mango } \\
\text { by Australian households }\end{array}$} \\
\cline { 2 - 10 } & \multicolumn{3}{c}{ Blue water } & WF & \multicolumn{3}{c}{ Blue water } \\
& VWC & impact & WF & (Aust-eq) & VWC & impact & WF & (Aust-eq) \\
& $(\mathrm{I})$ & $(\mathrm{I})$ & $(\mathrm{I})$ & $(\mathrm{I})$ & (Gl) & (Gl) & (Gl) & (Gl) \\
\hline Consumed fruit & 2429 & 931 & 41 & 101 & 37.7 & 14.4 & 0.63 & 1.56 \\
Distribution waste & 1921 & 736 & 32 & 80 & 29.8 & 11.4 & 0.50 & 1.24 \\
Consumer waste & 867 & 332 & 14 & 36 & 13.5 & 5.2 & 0.22 & 0.56 \\
Total & 5218 & 1999 & 87 & 217 & 81.0 & 31.0 & 1.35 & 3.36 \\
\hline
\end{tabular}

B. G. Ridoutt et al.

Title Page

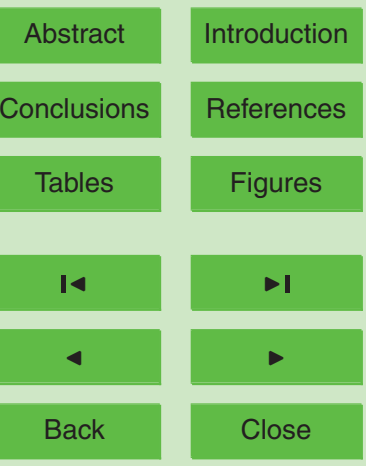

Full Screen / Esc

Printer-friendly Version

Interactive Discussion 


\section{HESSD}

$6,5085-5114,2009$

\section{Consumptive water} use associated with food waste

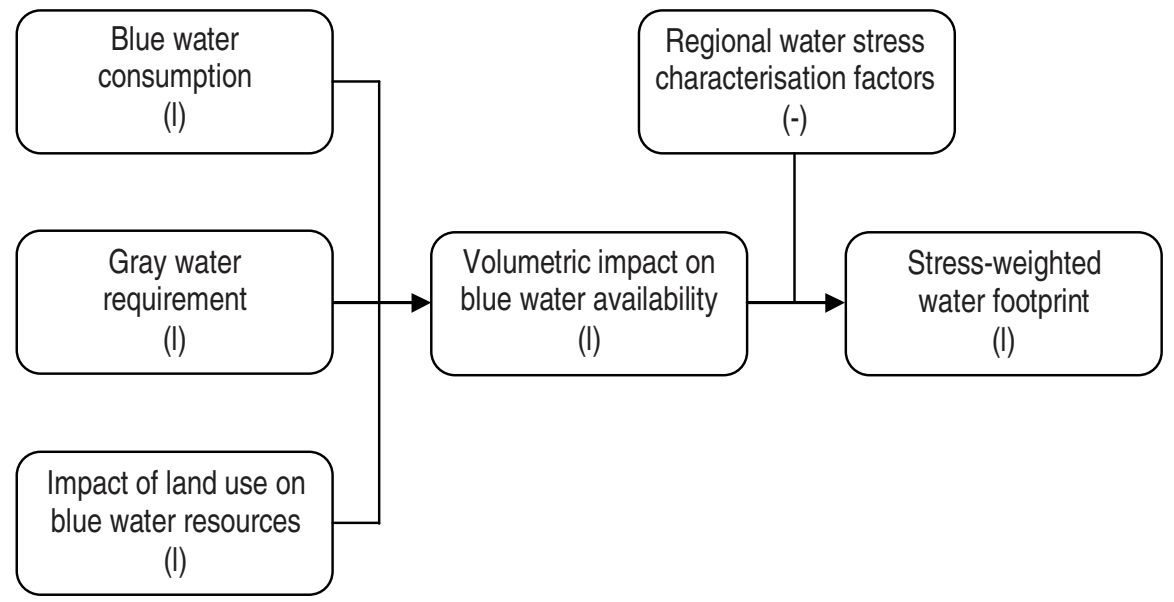

B. G. Ridoutt et al.

Fig. 1. Revised method of calculating product water footprints incorporating water stress characterisation factors (Ridoutt and Pfister, 2009).

Title Page

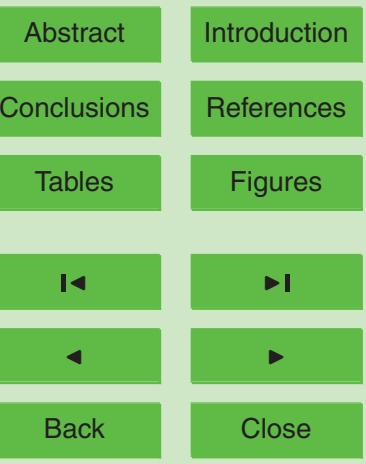

Full Screen / Esc

Printer-friendly Version

Interactive Discussion 


\section{HESSD}

$6,5085-5114,2009$

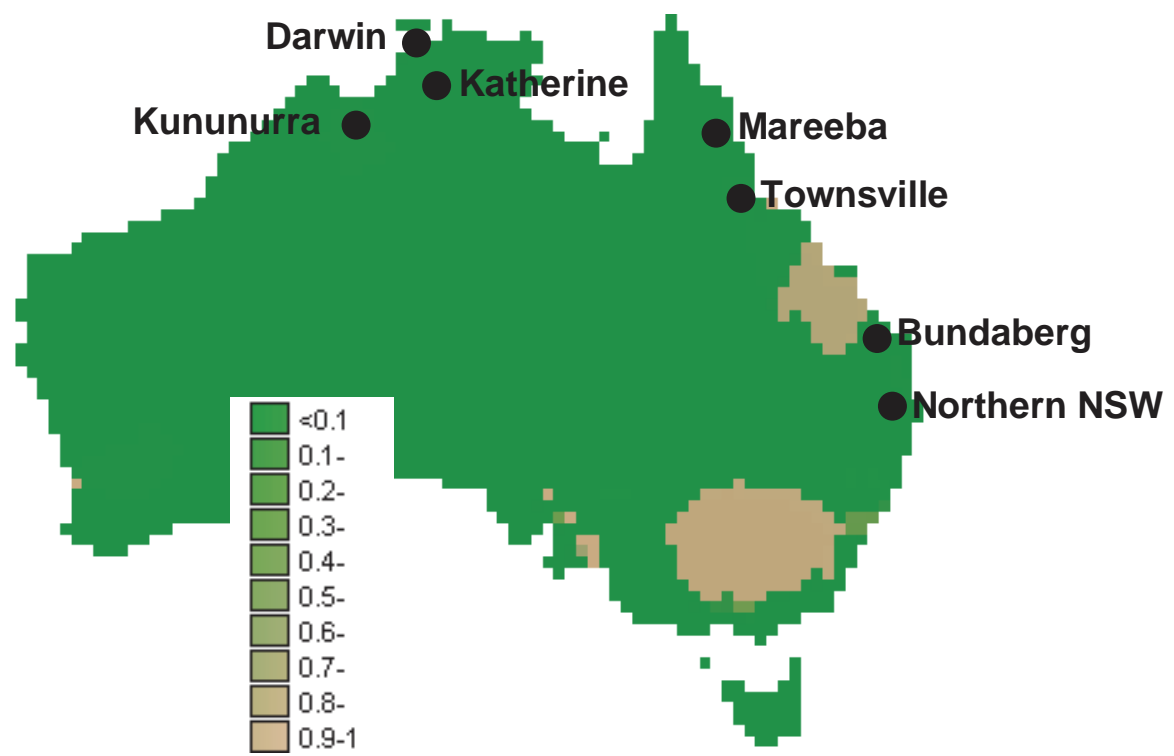

Consumptive water use associated with food waste

B. G. Ridoutt et al.

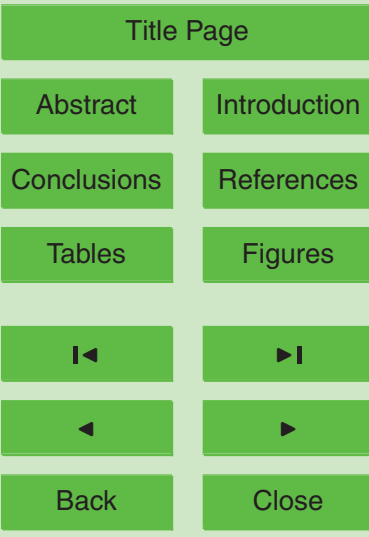

Fig. 2. Map of the Water Stress Index (WSI) for Australia (Pfister et al., 2009) showing the major mango producing regions.

Full Screen / Esc

Printer-friendly Version

Interactive Discussion 


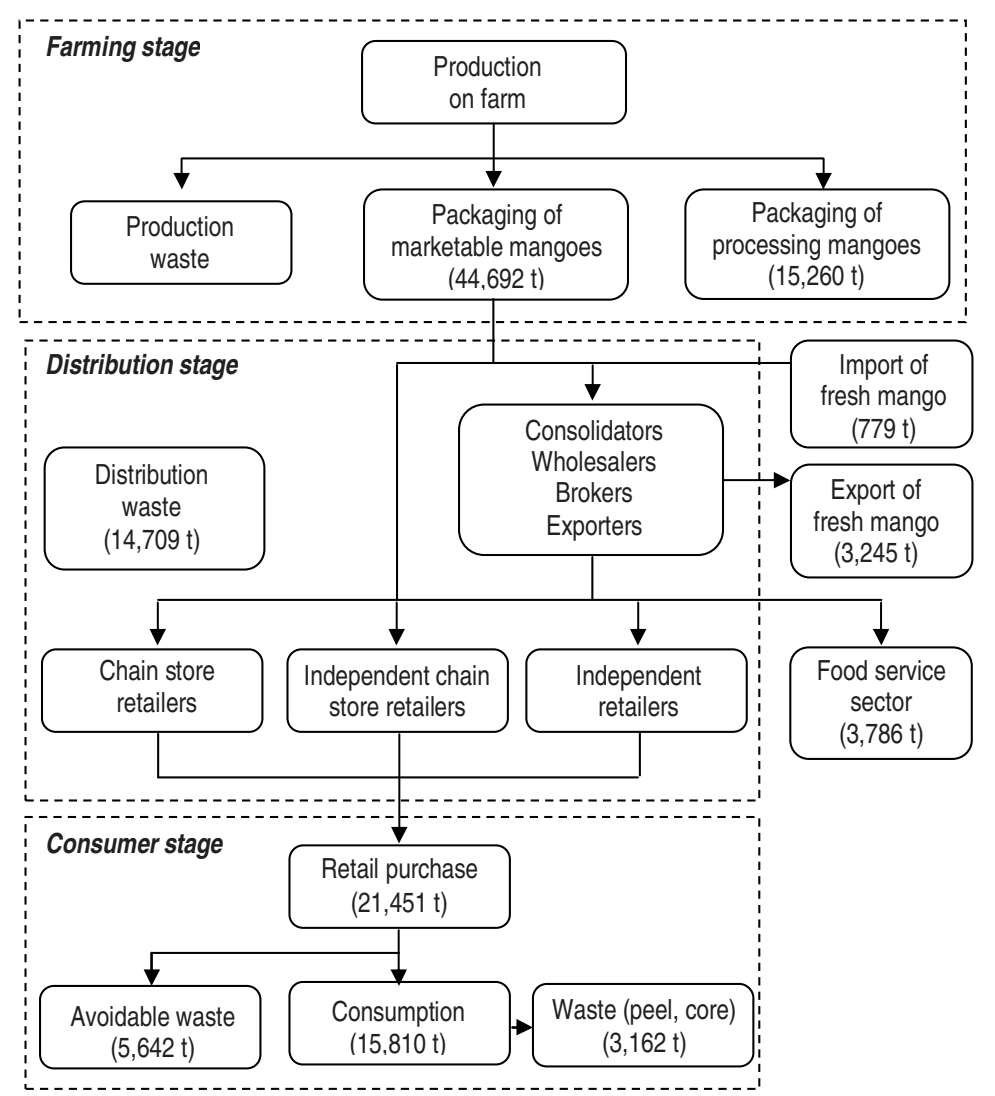

Fig. 3. Food chain for Australian-grown fresh mango to Australian households highlighting distribution and consumption waste.

\section{HESSD}

$6,5085-5114,2009$

\section{Consumptive water use associated with food waste}

B. G. Ridoutt et al.

\section{Title Page}

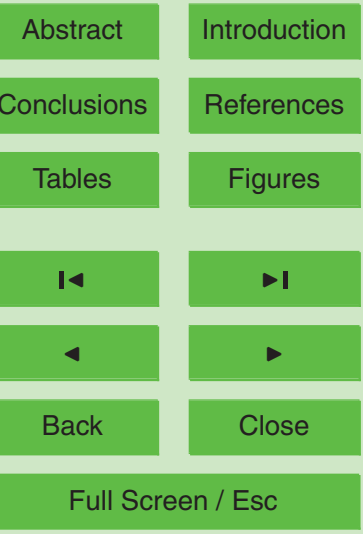

Printer-friendly Version

Interactive Discussion 